J Am Chem Soc. 2006 December 27; 128(51): 16518-16519. doi:10.1021/ja067720b.

\title{
Diindolylquinoxalines:
}

\section{Effective Indole-Based Receptors for Phosphate Anion}

\author{
Jonathan L. Sessler, Dong-Gyu Cho, and Vincent Lynch \\ Department of Chemistry and Biochemistry and Institute for Cellular and Molecular Biology, 1 \\ University Station A5300, The University of Texas at Austin, Austin, Texas 78712-0156
}

\section{Abstract}

The synthesis of a new series of 2,3-diindol-3'yl quinoxalines (DIQ), as well as a comparison of their anion recognition properties to those of our previously reported pyrrole based sensors, 2,3dipyrrol-2'yl quinoxalines (DPQ) is reported. To the best of our knowledge, this new DIQ system represents the first example of a free-standing indole-based small molecule receptor for which evidence of anion binding is available both in solution and in the solid-state. It also provides one of the few structurally characterized neutral receptor-dihydrogen phosphate complexes. This work thus serves to demonstrate the utility of indoles as an anion recognition motif.

Anions are ubiquitous in biological milieus. Among the most important physiologically relevant anions is inorganic phosphate. Not only does it play a critical role in energy storage and signal transduction, ${ }^{1}$ it recognized as essential structural element in teeth and bones. ${ }^{2}$ On the other hand, elevated serum phosphate levels can result in calcification of tissues ${ }^{3}$ and is a recognized problem in patients suffering from chronic kidney failure. Phosphate is also a key pollutant whose role in the eutrophication of waterways is well recognized. ${ }^{4}$ This diversity of function has stimulated considerable current interest devoted to the recognition and sensing of phosphate anions. ${ }^{5}$ Increasingly, efforts in this area have focused on the use of acyclic small molecule receptors, ${ }^{4}$ including those based on amide, sulfonamide, urea, and pyrrole recognition units. While each of these motifs presents certain advantages, there is incentive to explore additional putative binding subunits that could be used to generate new receptor systems. One such motif is indole, a potential hydrogen bond donor that has yet to be exploited extensively in the area of anion sensor development. Indeed, currently only indolocarbazoles $\mathbf{1}^{6}$ and bis(indolyl)methane, $\mathbf{2}^{7}$ are known to the best of our knowledge, and, in the case of the latter system, quantitative binding studies were not fully carried out. Thus, there remains a need to explore the fundamental anion binding properties (e.g., selectivity, affinity) of indolebased receptors. Towards this end, we report here the synthesis of a new series of 2,3-diindol -3'yl quinoxalines (DIQ, 6 and 7), as well as a comparison of their anion recognition properties to those of our previously reported pyrrole based sensors, 2,3-dipyrrol-2'yl quinoxalines (DPQ, 3). ${ }^{8}$ To the best of our knowledge, this new DIQ system, which relies on $\beta$-connectivity, represents the first example of an indole-based small molecule receptor for which evidence of anion binding is available both in solution and in the solid-state. It also provides one of the few structurally characterized neutral receptor-dihydrogen phosphate complexes. ${ }^{9}$

sessler@mail.utexas.edu.

Supporting Information Available: Details describing the synthesis and characterization of compound $\mathbf{6}$ and 7, details of fitting binding curves, and crystallographic data (CIF). This material is available free of charge via the Internet at http://pubs.acs.org. 
<smiles>c1ccc2c(c1)[nH]c1c2ccc2c3ccccc3[nH]c21</smiles>

1

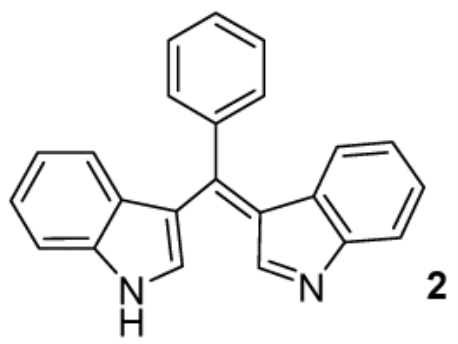

2

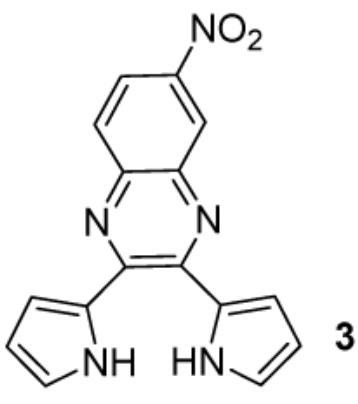

Receptors 6 and 7 require very short syntheses. Although the synthesis of receptor $\mathbf{6}$ was not clearly described in the literature, the syntheses of 2,3-diindol-3'yl diketone $5^{10}$ and receptor $6^{11}$ have been published. In the event, we have found that intermediate $\mathbf{5}$ is easily prepared by the reaction of indole Grignard reagent with indolyl oxaacethyl chloride 4 . Subsequent reaction between the resulting diketone $\mathbf{5}$ and either $o$-phenyldiamine or its mono nitro analogue gave the final receptors 6 and 7 in unoptimized yields of 48 , and, 30 respectively.

The association constants $\left(K_{\mathrm{a}}\right)$ of receptors $\mathbf{6}$ and $\mathbf{7}$ were determined from standard UV-vis absorption titrations carried out in dichloromethane. Fig 1 presents the observed changes in the UV-vis spectrum of receptor 7 recorded in dichloromethane upon the addition of tetrabutylammonium hydrogen phosphate $\left(\mathrm{TBA}-\mathrm{H}_{2} \mathrm{PO}_{4}\right.$ ). In the absence of the anion, an absorption maximum is seen at $434 \mathrm{~nm}$. Upon addition of $\mathrm{H}_{2} \mathrm{PO}_{4}{ }^{-}$, a large bathochromic shift was observed $\left(\Delta \lambda_{\max }=40 \mathrm{~nm}\right)$. The resulting titration revealed several isosbestic points as expected for a 1:1 binding stoichiometry. Similar isosbestic points were also observed during the course of titrations carried out with $\mathrm{F}^{-}, \mathrm{Cl}^{-}, \mathrm{HSO}_{4}{ }^{-}$and $\mathrm{BzO}^{-}$anions as well (all as TBA salts). This binding stoichiometry was confirmed in solution by Job plots and, in the case of receptor $\mathbf{7}$ and dihydrogen phosphate anion, by a single crystal X-ray analysis carried out in the solid state (cf. Fig. 3 and discussion below).

Association constants determined from these titrations are summarized in Table 1. An inspection of this table reveals that in the case of receptor $\mathbf{6}$ the greatest affinity is displayed for dihydrogen phosphate anion, followed by $\mathrm{F}^{-}>\mathrm{BzO}^{-}>\mathrm{Cl}^{-}>\mathrm{HSO}_{4}{ }^{-}$. This same table also confirms that, as proved true in the case of the corresponding DPQ systems, the nitro-bearing receptor $\mathbf{7}$ shows higher affinities across the board than does the unsubstituted system $\mathbf{6}$. This result is attributed to the electron withdrawing nitro group, which serves to increase the pyrrole $\mathrm{NH}$ acidity. Consistent with this postulate, receptor 7 shows biphasic behavior ${ }^{12}$ when subject to titration with fluoride anion in dichloromethane. Under these conditions, the fluoride anion presumably acts as both a general base and as an anionic substrate (cf. Supporting Information).

Among the anionic substrates for which clean binding behavior is seen, receptor $\mathbf{7}$, like its congener $\mathbf{6}$, shows good selectivity for phosphate anion $\left(K_{\mathrm{a}}\left(\mathrm{H}_{2} \mathrm{PO}_{4}\right) / K_{\mathrm{a}}(\mathrm{Cl})=42, K_{\mathrm{a}}\left(\mathrm{H}_{2} \mathrm{PO}_{4}\right) /\right.$ $K_{\mathrm{a}}(\mathrm{BzO})=7$ and $\left.K_{\mathrm{a}}\left(\mathrm{H}_{2} \mathrm{PO}_{4}\right) / K_{\mathrm{a}}\left(\mathrm{HSO}_{4}\right)=80\right)$. Such a high inherent selectivity was not seen in either the corresponding DPQ systems $\left(K_{\mathrm{a}} \text { (rept. 7)/ } K_{\mathrm{a}} \text { (rept. 3) }=250 \text { for } \mathrm{H}_{2} \mathrm{PO}_{4}^{-}\right)^{8}$ or in the indolecarbazole ${ }^{6}$ based receptors reported recently by Beer. We ascribe this selectivity to the presence of the $\beta$-connectivity linking the two indole motifs to the quinoxaline core; this provides a more open (and potentially less rigid) cavity that is expected to favor binding of this relatively larger anionic substrate.

Further support for the notion that compound $\mathbf{7}$ can act as a dihydrogen phosphate anion receptor comes from a single crystal $\mathrm{X}$-ray diffraction analysis of the complex formed between 7 and TBA $\cdot \mathrm{H}_{2} \mathrm{PO}_{4}$. This structure reveals the presence of two different phosphate-receptor interactions in the solid state. In one complex, a molecule of receptor $\mathbf{7}$ interacts with two 
phosphate anions that, in turn, interact with one another via a hydrogen bonds. In the other complex, receptor $\mathbf{7}$ binds three phosphates that again exist in a self-associated network (cf. Fig. 3). As the result of these and other hydrogen bonding interactions, a series of infinite phosphate channels and wires is observed in the solid state. ${ }^{13}$ Nonetheless, the overall anionto-receptor binding stoichiometry is $1: 1$, as expected based on the solution phase Job plot analyses.

A further notable feature of receptor $\mathbf{7}$ is that color changes are seen upon the addition of $\mathrm{F}^{-}$ and $\mathrm{H}_{2} \mathrm{PO}_{4}{ }^{-}$anions (Figure 2). Such color changes are considered a useful feature of anion receptors in that they allow analytes to be detected easily without recourse to spectrometers. 14

In summary, the new indole-based receptors 6 and $\mathbf{7}$ provide a new series of anion receptors that are particularly effective for dihydrogen phosphate anion. Receptor $\mathbf{7}$ allows for the visual detection of this anion via the production of a simple, anion-triggered color change (as well as fluoride for which less clean binding behavior is seen). The interaction between $\mathrm{H}_{2} \mathrm{PO}_{4}{ }^{-}$and receptor 7 also gives rise to the formation of a unique extended structure in the solid state, leading to the suggestion that systems such as $\mathbf{7}$ could be used as the basis for new engineered crystalline materials. We are currently studying this possibility while working to produce more elaborate indole-based receptors.

\section{Supplementary Material}

Refer to Web version on PubMed Central for supplementary material.

\section{Acknowledgment}

This work was supported by the National Institutes of Health (GM 58907 to J.L.S.)

\section{References}

(1). Saenger, W. Principles of Nucleic Acid Structure. New York; Springer Verlag: 1988.

(2) (a). Hruska K, Teitlebaum S. New Engl. J. Med 1995;333:166-175. [PubMed: 7791820] (b) Robinson C. Dental Digest 2000:1-3.

(3) (a). Block GA, Port FK. Am. J. Kidney Dis 2000;35:1226-1237. [PubMed: 10845841] (b) Delmez JA, Slatopolsky E. Am. J. Kidney Dis 1992;19:303-317. [PubMed: 1562018]

(4) (a). Sessler, J.; Gale, PA.; Cho, W-S. Anion Receptor Chemistry. Cambridge, UK: 2006. The Royal Society of Chemistry. (b) Beer PD, Gale PA. Angew. Chem., Int. Ed 2001;41:486-516.

(5) (a). Kendo S-I, Hiraoka Y, Kurumatani N, Yano Y. Chem.Comm 2005:1720-1722. [PubMed: 15791310] (b) Seong HR, Kim D-S, Kim S-G, Choi H-J, Ahn KH. Tetrahedron Lett 2004;45:723727. (c) Chmielewski MJ, Charon M, Jurczak J. Org. Lett 2004;6:3501-3504. [PubMed: 15387533] (d) Han MS, Kim DH. Angew. Chem., Int. Ed 2002;41:3809-3811. (e) Kuo L-J, Liao J-H, Chen C-T, Huang C-H, Chen C-S, Fang J-M. Org. Lett 2003;5:1821-1824. [PubMed: 12762661] (f) Tobey SL, Anslyn EV. Org. Lett 2003;5:2029-2031. [PubMed: 12790520] (g) Anzenbacher P, Jursikova K, Sessler JL. J. Am. Chem. Soc 2000;122:9350-9351. (h) Beer PD, Dickson CAP, Fletcher N, Goulden AJ, Grieve A, Hodacova J, Wear T. J. Chem. Soc., Chem. Commun 1993:828830.

(6). Curiel D, Cowley A, Beer PD. Chem. Comm 2005:236-238. [PubMed: 15724197]

(7). He X, Hu S, Liu K, Guo Y, Xu J, Shao S. Org. Lett 2006;8:333-336. [PubMed: 16408908]

(8) (a). Black CB, Andrioletti B, Try AC, Ruiperez C, Sessler JL. J. Am. Chem. Soc 1999;121:1043810439. (b) Sessler JL, Maeda H, Mizuno T, Lynch VM, Furuta H. J. Am. Chem. Soc 2002;124:13474-13479. [PubMed: 12418900]

(9) (a). X-ray structures of (di)hydrogen phosphate bound to neutral receptor molecules are limited; see, for instance:Yin Z, Zhang Y, He J, Cheng J-P. Terahedron 2006;62:765-770. (b) Amendola V, 
Boiocchi M, Esteban Gómez, D. Fabbrizzi L, Monzani E. Org. Biomol. Chem 2005;3:2632-2639. [PubMed: 15999198] (c) Král V, Furuta H, Shreder K, Lynch V, Sessler JL. J. Am. Chem. Soc 1996;118:1595-1607.

(10) (a). Bergman J, Janoik T, Johnsson AL. Synthesis 1999;4:580-582. (b) Bergman J, Carlsson R, Sjöberg B. J. Heterocycl. Chem 1977;14:1123-1134.

(11). Lopatinskaya KY, Skorobogatova ZM, Sheinkman AK, Zaritovskaya TA. Chem. Heterocycl. Compd 1985;21:675-679.

(12). Anzenbacher P, Jursikova K, Shriver JA, Miyaji H, Lynch VM, Sessler JL, Gale PA. J. Org. Chem 2000;65:7641-7645. [PubMed: 11076627]

(13). For an example of a previously reported neutral molecule receptor system that forms infinite chains in the solid state upon interacting with phosphate, see ref. $9 \mathrm{~b}$.

(14) (a). Miyaji H, Sato W, Sessler JL. Angew. Chem., Int. Ed 2000;39:1777-1780. (b) Anzenbacher P, Jursikova K, Sessler JL. J. Am. Chem. Soc 2000;122:9350-9351. 

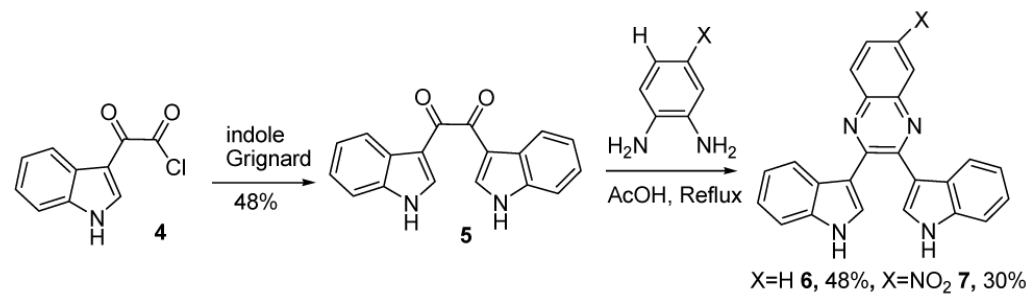

Scheme 1.

Synthetic Scheme 

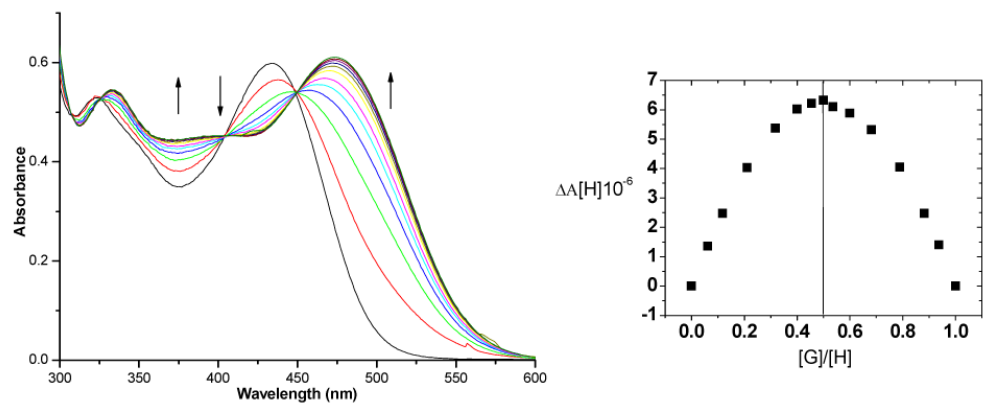

Figure 1.

Evolution of the UV-vis spectrum of receptor $7\left(3.99 \times 10^{-5} \mathrm{M}\right.$ in dichloromethane) seen during upon titration with tetrabutylammonium hydrogen phosphate (TBA $\left.\cdot \mathrm{H}_{2} \mathrm{PO}_{4}\right)$ (0 to 10 equiv.). (Inset) Job plot for the interaction between receptor 7 and $\mathrm{TBA} \cdot \mathrm{H}_{2} \mathrm{PO}_{4}$. 


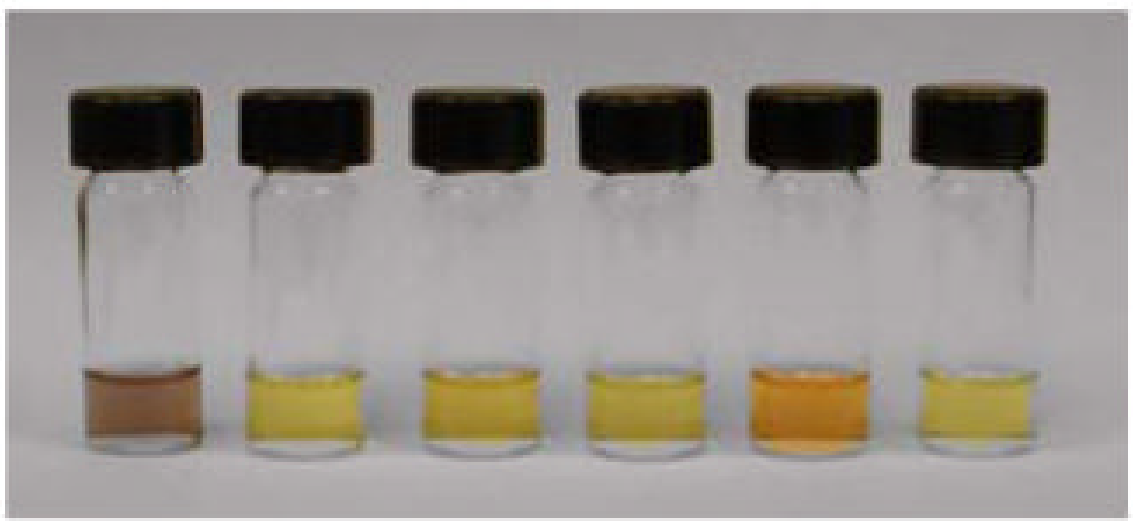

Figure 2.

Color changes observed upon the addition of anions (10 equiv.) to otherwise identical solutions of receptor 7 (4.34 $\times 10^{-5} \mathrm{M}$ in dichloromethane). From left to right; $\mathrm{F}^{-}+\mathbf{7}, \mathrm{Cl}^{-}+\mathbf{7}, \mathrm{BzO}^{-}+$ 7, $\mathrm{HSO}_{4}^{-}+7, \mathrm{H}_{2} \mathrm{PO}_{4}^{-}+7,7$. 
(a)

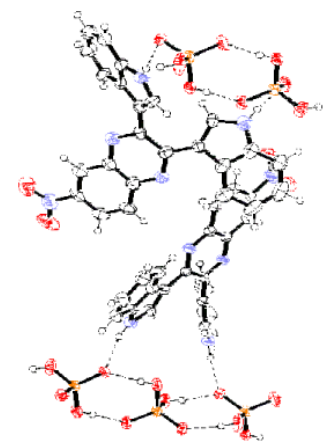

(b)

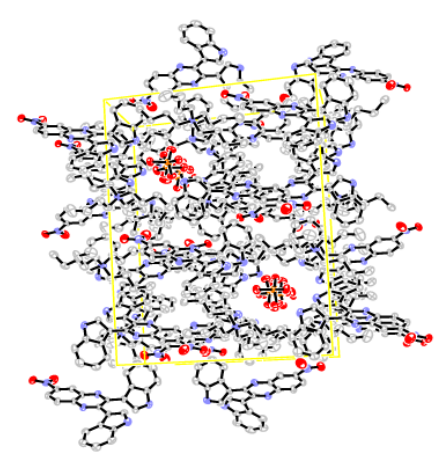

Figure 3.

Single crystal X-ray diffraction structure of receptor 7-TBA $\cdot \mathrm{H}_{2} \mathrm{PO}_{4}$. Thermal ellipsoids are scaled to the $50 \%$ probability level. Most hydrogen atoms and the TBA cations have been omitted for clarity. (a) View illustrating the two types of phosphate bound receptor 7 complexes found in the solid state structure; (b) view of the (receptor 7.TBA. $\left.\mathrm{H}_{2} \mathrm{PO}_{4}\right)_{8}$ complex seen in the unit cell. 
Table 1

Anion Binding Constants $\left(K_{\mathrm{a}} ; \mathrm{M}^{-1}\right)^{a}$ for Receptors 6 and 7 in Dichloromethane at $22^{\circ} \mathrm{C}$

\begin{tabular}{lrrr}
\hline & $\mathbf{3}^{\mathbf{8}}$ & $\mathbf{6}$ & $\mathbf{7}$ \\
\hline $\mathrm{F}^{-}$ & 118000 & $-b$ \\
$\mathrm{Cl}^{-}$ & 65 & 2100 & 170 \\
$\mathrm{HSO}_{4}^{-}$ & $\mathrm{N} . \mathrm{D}$ & 80 & 600 \\
$\mathrm{BzO}^{-}$ & $\mathrm{N} . \mathrm{D}$. & 250 \\
$\mathrm{H}_{2} \mathrm{PO}_{4}^{-}$ & 80 & 6800 & 2700 \\
& & $20000^{-}$ & \\
\hline
\end{tabular}

${ }^{a}$ Values were determined by UV-vis spectroscopic titrations; errors are $< \pm 10 \%$. All anions were used in the form of their respective tetrabutylammonium (TBA) salts.

${ }^{b}$ A reliable binding constant could not be determined due to the observation of biphasic behavior.

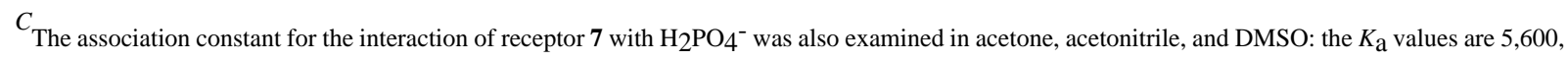

2,400 and $300 \mathrm{M}^{-1}$, respectively. N.D. - not determined. 